\title{
Active Tephra 2010: International field conference on tephrochronology
}

\section{Kirishima City, Japan, 9-17 May 2010}

DaVID J. LoWE

Department of Earth and Ocean Sciences, University of Waikato, Hamilton, New Zealand; d.lowe@waikato.ac.nz

\section{INTAV meets in Japan}

INQUA's international focus group on tephrochronology and volcanism (INTAV) met in Kirishima in southern Kyushu. A total of 76 participants (including 25 students) from 12 countries attended. Around 50 oral papers, including six invited keynote talks, were presented over three days alongside nearly 40 posters. Financial support from PAGES and the INQUA INTREPID project enabled 11 young scientists to attend the conference. Further support was provided by the Tokyo Geographical Society, Paleo, West Japan Engineering, Asahi, JAQUA, and the city of Kirishima.

\section{Papers and Eyjafjöll session}

The conference commenced with two public lectures by David Lowe (Waikato University) "Connecting with our past: using tephras and archaeology to date the Polynesian settlement of Aotearoa/New Zealand" and by Hiroshi Machida (Tokyo Metropolitan University) "Widespread tephras originating from Kagoshima occurring in northeast Asia and adjacent seas."

A highlight was a special session on the 2010 eruptions from the Icelandic Eyjafjöll volcano, which attracted local TV and newspaper coverage. This Eyjafjöll session included talks by Chris Hayward and Thor Thordarson (both Edinburgh University) and by Siwan Davies (Swansea University). It became evident that this eruption would provide an excellent opportunity to enhance knowledge on cryptotephras from Icelandic volcanoes, which are being increasingly utilized for time control in the Northern Hemisphere ice-core, marine and terrestrial records (Davies et al., 2010). An INTAV-sponsored meeting on the eruption and its implications for tephra studies will be held in Edinburgh on May 5-6, 2011 and a tephrochronology session is scheduled the INQUA Congress in Bern in July 2011.

Further keynote presentations were given by Nick Pearce (Aberystwyth University) on developments and applications in LA-ICP mass spectrometry, Duane Froese (Alberta University) on YukonAlaskan Quaternary permafrost studies linked by tephras, Siwan Davies (Swansea

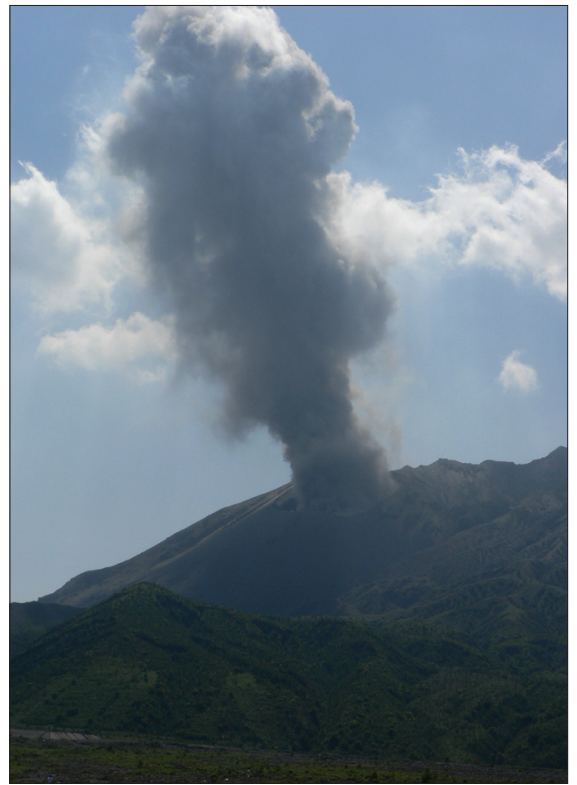

Figure 1:Right on cue: a small eruption of Showa Crater of Sakurajima volcano on Day 1 of the intra-conference fieldtrip (12 May). Photo: Anja Moebis

University) on tephras in Greenland ice cores, Mitsuhiro Nakagawa (Hokkaido University) on petrology and eruption processes of Shikotsu and Aira calderas, Simon Blockley (London University) on tephra age-modeling including Bayesian studies, and Takeshi Nakagawa (Newcastle University) on recent geochronological and analytical work of the exceptional varve sequence of Lake Suigetsu.

\section{Field trips}

An intra-conference fieldtrip included a visit to the Uenohara Jomon-no-mori archeological centre where a village from the Jomon period (ca. 9.5 ka ago) had been preserved under tephra deposits. The group was then treated to a stunning and apt backdrop for a tephrabased meeting: the Sakurajima volcano has been active since 1955, with more than 8670 eruptions since then. Around 500 eruptions had already taken place in 2010 prior to this visit. Two small vulcanian eruptions took place in Showa crater, by a remarkable coincidence, whilst the group visited the eastern flank of the volcano at the closest point to the active crater (Fig. 1). Furthermore, participants were taken to outcrops of layers of tephras and buried soils dating back $30 \mathrm{ka}$, to the spectacular Jomon Tenjindan archeological site, and to a magnificent coastal exposure, $\sim 20-30 \mathrm{~m}$ high, of the deposits of the voluminous Aira tephra formation dated at ca. $30 \mathrm{ka}$.

The conference was followed by a three day trip to the Unzen volcano where deposits from the 1990-1995 eruption series, including lava domes, block-and-ash flow deposits, and pyroclasic flow deposits, were seen. Visited sites also included the extremely impressive, $25-\mathrm{km}$-wide, Aso caldera and associated deposits, the volcanic vents in central Kyushu, and the volcanoes of Kuij and Yufi-Tsurumi in northeastern Kyushu.

\section{Conclusion}

The conference and field trips were remarkable. As one veteran participant remarked, "tephra studies have never been so healthy". The rise of young tephrochronologists was especially prominent and augurs well for future research and leadership of the discipline. Papers from the meeting are to be published in a volume of Quaternary International that will also commemorate the career of Hiroshi Machida.

\section{Reference}

Davies, S.M., Larsen, G., Wastegård, S., Turney, C.S.M., Hall, V.A., Coyle, L. and Thordarson, T., 2010: Widespread dispersal of Icelandic tephra: how does the Eyjafiöll eruption of 2010 compare to past Icelandic events? Journal of Quaternary Science, 25: 605-611. 